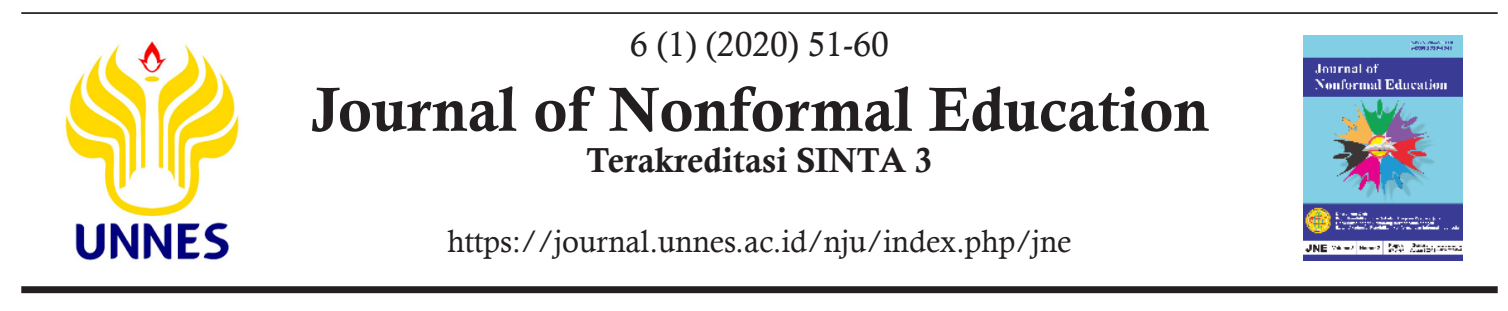

\title{
Effect of Flippeed Classroom Models and Creative Thinking of Science Literation Students
}

\author{
Wiwi Susanti ${ }^{\bowtie}$, Asep Supena, Ucu Cahyana
}

DOI: http://dx.doi.org/10.15294/jne.v6i1.21616

Universitas Negeri Jakarta, Indonesia

\section{History Article \\ Submitted 27 October 2019 Revised 24 January 2020 Accepted 4 February 2020}

\section{Keywords}

flipped classroom model; expository model; scientific literacy

\begin{abstract}
The flipped classroom model, which is often heard in recent years, is known as a new pedagogical approach in which traditional instruction is reversed. The study aims to determine the effect of the flipped classroom model and creative thinking on the scientific literacy of grade VI students of SDN Guntur 01, South Jakarta. This research uses a $2 \times 2$ factorial design. The research sample was divided into two treatment groups, namely the experimental class and the control class. The experimental class was given treatment by carrying out the learning model of the flipped classroom , while the control class was given treatment by carrying out the expository model learning. The results showed: (1) there was a difference in scientific literacy between the experimental class and the control class, with scientific literacy higher than the control class. (2) there is a difference in scientific literacy between groups of students with high levels of creative thinking in the experimental class $\left[\mathrm{A}_{1} \mathrm{~B}_{1}\right]$ and the control class $\left[\mathrm{A}_{2} \mathrm{~B}_{1}\right]$. (3) there is a difference in scientific literacy between groups of students with low creative thinking levels in the experimental class $\left[\mathrm{A}_{1} \mathrm{~B}_{2}\right]$ and the control class $\left[\mathrm{A}_{2} \mathrm{~B}_{2}\right]$. (4) there is an effect of interaction between learning models and creative thinking on scientific literacy. Purpose of the flipped classroom model is to use face to face time more effectively in the learning process. There are many definitions related to flipped classroom is a student-centred learning method consisting of two parts with interactive learning activities during lesson and individual teaching based on computer out of lesson.
\end{abstract}




\section{INTRODUCTION}

One parameter that is internationally recognized and is often used by various countries around the world to measure the quality of the education system is to measure the ability of scientific literacy among students. Various countries recognize that the ability of students' scientific literacy is one important indicator that shows the quality of the education system. The higher the ability of scientific literacy among students, the higher the quality of the education system. That is why education practitioners, scientists, and policy makers in the field of education put the achievement of scientific literacy skills among students as the main focus of educational reform, with the most important goal being to prepare them to become future citizens who understand and can adapt to scientific progress (MartinezHernandez, Ikpeze, \& Kimaru, 2015).

Science literacy was initially understood only as knowing science, but along with the dynamics of the progress of the world of education and the increasingly sophisticated technological inventions, the meaning of scientific literacy developed in a wider area. DeGraff argues that scientific literacy in board terms and argued that an open-ended approach, free of benchmarks and high stakes testing, allows teachers and students more freedom to choose from a wide variety of science contents and methodologies (Alzoubi, et al., 2016). According to DeGraff, scientific literacy in a broad sense is an approach that is open, free from benchmarks, and has high testing so that it allows teachers and students to have a lot of freedom to choose science content and methodology.

The meaning of scientific literacy in that broad sense reflects two different views. First is the view that considers that scientific literacy as a content of scientific knowledge taught in schools. Second is the view that considers that scientific literacy is a condition of people who understand science and that it is an important prerequisite to being able to adapt to the challenges of a rapidly changing and dynamic world (Arnold-Garza, 2014).

In this regard, the OECD (Organization for Economic Cooperation and Development), an international institution that houses the PISA (Program for International Students Assessment) offers a meaning of the concept of scientific literacy that is synthesized, through the following statements a scientific literacy is the ability to engage with science-related issues, and with the ideas of science, as a re fl ective citizen. A scien- tifically literate person is willing to engage in reasoned discourse about science and technology, the which requires the competencies to: (1) explain phenomena scientifically recognize, o ff er and Evaluate explanations for a range of natural and technological phenomena; (2) evaluate and design scientific inquiry subscribe and appraise scientific investigations and propose ways of addressing scientifically questions; (3) interpret data and evidence scientifically analyze and evaluate data, claims and arguments in a variety of representations and draw appropriate scientific conclusions (Berman, \& Elizabeth, 2017).

The expository model is indeed a learning model that has been widely criticized by experts because the practice of learning only emphasizes the process of verbally delivering material from an educator to a group of students with the intention that students understand and master the material optimally (Sanjaya, 2016). The model was also criticized because it was built based on the teacher centered instruction paradigm that views students as nothing but glass or paper that is still empty. Therefore the teacher is obliged to fill the glass or write down the blank paper to the full through the learning process. The learning media developed in this model are printed and audiovisual. Print Learning Media in the form of modules following the principles of learning (Eddy \& Suryono, 2019).

Creative thinking is a brain activity (brain) that mobilizes all his thinking power to bring up various ideas and new thoughts. The various new ideas and thoughts can be original or the results of the design of existing ideas so as to produce thoughts that are different from before. Sharon Bailin explained the ability to think creatively, as follows a creative thinking, on the other hand, is precisely the type of thinking which can transcend frameworks. It is inventive, imaginative, and involves the generation of new ideas. Because it involves breaking out of old frameworks, creative thinking is thought to exhibit characteristics which are precisely the opposite of critical thinking. It is essentially generative, spontaneous, and non-evaluative. It involves divergent thinking, rule-breaking, the suspension of judgment, and leaps of imagination. And, instead of being characterized by logic or appeal to reasons, it relies heavily on institutions, and unconscious of process (Baumtrog, 2017).

Creative thinking is a type of thinking that is actually out of the framework. It is inventive, imaginative, and involves new ideas. Because out of the old framework, creative thinking shows characteristics that are just the opposite of criti- 
cal thinking. Creative thinking is basically generative, spontaneous, and non-evaluative. Creative thinking involves different thoughts, sometimes breaking the rules, ignoring judgments, and reflecting a leap in the imagination. And, instead of being characterized by logic or based on certain reasons or arguments, creative thinking is highly dependent on instincts and processes that are not realized.

The personal needs of individuals have changed through the influence of external factors such as rapidly increasing population and developing technology. Traditional instruction methods have become inadequate in meeting different learning demands. The reason of this is that students do not feel themselves comfortable and learning environment is not appropriate for them in the traditional instruction system where the teacher is in the center of the learning process (Cooper, \& Valentine, 2001). Students are passive learners in traditional instruction systems, which causes students to be inefficient during learning process.

More efficient education approaches must be applied in order to compensate these demands. In this regard, innovative learning approaches assisted by technological opportunities can be used. Indeed, giving more space and time to technology in learning process will provide students with contemporary skills and improve education system by providing a real education reform (Overmyer, 2014). Creating technology-based training environments in the education system will bring innovation to educational settings. The solution offered to the problem is tooptimize the implementation of the parent class through methods in the process of exchanging ideas and experiences (Fauziah \& Kusumawardani, 2019).

One of the most effective ideas to carry out the reforms required by the age of education is flipped classroom model. The flipped classroom model, which is often heard in recent years, is known as a new pedagogical approach in which traditional instruction is reversed. This model focuses on group learning rather than individual learning. In flipped classrooms, teacher guides the concepts effectively by creating a dynamic and interactive learning environment (Aaron, et al., 2014).

Traditional flipped classroom model as "what is done at school done at home, homework done at home completed in class" (Bergmann, et al., 2015). Basic information is provided by the resources and materials shared by teacher before class. Some activities such as problem solving, discussion, brainstorming is performed during class time and teacher has the role of guide in this process. In flipped classroom approach, teachers prepare some videos about the subjects that they are going to teach. Students are expected to watch the videos before coming to the classes. The lesson starts with short questions and answers. If there are points in lecture that are not understood, they are explained.

Research entitled "Using the Flipped Classroom Model in the Development of Basic Language Skills and Enriching Activities: Digital Stories and Games". Research using the action research method was carried out in grade IV elementary school with 23 research subjects, consisting of 11 women and 12 men. In this study, the measured variable is the flipped classroom model as the independent variable and digital story activities and games-based activities as moderator variables, as well as basic language skills and activities that enrich each of them as the dependent variable.

The study aims to determine the effect of the flipped classroom model and creative thinking on the scientific literacy of grade VI students of SDN Guntur 01, South Jakarta. This research uses a $2 \times 2$ factorial design. Purpose of the flipped classroom model is to use face to face time more effectively in the learning process. There are many definitions related to flipped classroom is a student-centred learning method consisting of two parts with interactive learning activities during lesson and individual teaching based on computer out of lesson.

\section{METHODS}

This study uses an experimental method, which is a research method used to find out, search for, and explore the influence or impact of a treatment on certain variables (Freddi, \& Alessandro, 2019). In the context of this study, what is wanted to be known, sought out, and explored is the effect of the application of the flipped classroom model and expository model on the ability of scientific literacy based on the classification of students' creative thinking abilities.

The research subjects were divided into two groups, namely the experimental class and the control class. The experimental group (class VI A) was treated by applying the flipped classroom model, and the control class (class VI B) was treated by applying the expository model. In each group (experimental class and control class), the research subjects were classified into two categories of students, namely students with high creative thinking abilities and students with low creative thinking abilities. Thus, overall this study 
wants to find, know, and explore the effect of two learning models (flipped classroom models and expository models) on students' scientific literacy abilities in terms of their level of creative thinking ability.

Based on that, the variables in this study consisted of independent variables, moderator variables, and bound variables with the following details: (1) the independent variables of the learning model, (2) the moderator variables were creative thinking, and (3) the dependent variables were scientific literacy abilities. The research design used was treatment by level $2 \times 2$ posttest only control design (Bausell, 1994).

Table 1. Design Treatment by Level 2 x 2 (Bausell, 1994)

\begin{tabular}{lcc}
\hline \multirow{2}{*}{$\begin{array}{l}\text { Creative } \\
\text { Thinking }\left(\mathrm{X}_{2}\right)\end{array}$} & \multicolumn{2}{c}{ Learning Model $\left(\mathrm{X}_{1}\right)$} \\
\cline { 2 - 3 } & $\begin{array}{c}\text { Flipped Class- } \\
\text { room }\left(\mathrm{X}_{1 \mathrm{a}}\right)\end{array}$ & $\begin{array}{c}\text { Ekspositori } \\
\left(\mathrm{X}_{1 \mathrm{~b}}\right)\end{array}$ \\
\hline $\begin{array}{l}\text { High Creative } \\
\text { Thinking }\left(\mathrm{X}_{2 \mathrm{a}}\right)\end{array}$ & $\left(\mathrm{Y}_{1 \mathrm{a}-2 \mathrm{a}}\right)$ & $\left(\mathrm{Y}_{1 \mathrm{~b}-2 \mathrm{a}}\right)$ \\
Low Creative & $\left(\mathrm{Y}_{1 \mathrm{a}-2 \mathrm{~b}}\right)$ & $\left(\mathrm{Y}_{1 \mathrm{~b}-2 \mathrm{~b}}\right)$ \\
Thinking $\left(\mathrm{X}_{2 \mathrm{~b}}\right)$ & &
\end{tabular}

Notes: $X_{1 a}=$ Students in the experimental class with the flipped classroom model; $\mathrm{X}_{1 \mathrm{~b}}=$ Students in the control class with expository models; $\mathrm{X}_{2 \mathrm{a}}=$ Students with high levels of creative thinking; $\mathrm{X}_{2 \mathrm{~b}}=$ Students with low levels of creative thinking; $Y_{1 \mathrm{a}-2 \mathrm{a}}=$ The ability of experimental class science literacy with a level of thinking creative height; $\mathrm{Y}_{1 \mathrm{a}-2 \mathrm{~b}}=$ The ability of experimental class science literacy with a level of thinking low creative; $Y_{1 b-2 a}=$ Control literacy skills of the control class with a level of creative thinking hight; $Y_{1 b-2 b}$ $=$ The ability of control class scientific literacy with a level of creative thinking low.

The treatment was given to two research classes, namely the experimental class and the control class for 10 meetings. The experimental class applies the flipped classroom model and the control class applies the expository model. The first meeting is used for the implementation of tests that measure creative thinking abilities and the 10th meeting is used for the implementation of tests that measure the ability of scientific literacy. Thus the treatment in the form of the application of learning models in each research class (the experimental class and the control class) is carried out at the 2 nd to 9 th meeting by two different teachers assuming that the two teachers have relatively the same competencies.

Before giving treatment, the two teachers were given signs in the form of learning scenarios (syllabus and lesson plans), the media needed, as well as instructions for implementing the flipped classroom and expository models.

\section{RESULT AND DISCUSSION}

The results showed the flipped classroom model combined with digital story activities and games-based activities can improve basic language skills. The measurements are carried out on aspects of listening, writing, visual literacy, imagination, technology literacy, social relations, effective communication, and motor skills. Research subjects showed a significant increase in basic language skills, both in the classroom and outside the classroom. Observations in the classroom are carried out by the teacher, while observations outside the classroom (at home) are carried out with the help of the students' parents (Maharani, et al., 2017).

During class time, students are given opportunity to learn by discussing. However, in traditional approach teaching of subject takes the most of course time (Bergmann et al., 2015). The flipped classromm model has many advantages for both individual learning process and in-class learning process. The advantages that (Fulton, 2012) expressed are; students can access lecture videos whenever and wherever they want, and it provides students to learn at their own speed. The students that are educated with this approach are encouraged to think both within and out of class (Kellinger, 2012). The model includes both active learning and the advantages of individual learning (Bishop \& Verleger, 2013). In addition to all these advantages, (Herreid, et al., 2012) reported that flipped classroom approach provides students more time to make inventive researches.

Despite the advantages of the flipped classroom model, there are some disadvantages. (Bristol, 2014) expressed the difficulties that may occur when the students do not watch the videos before coming to the class. According to (Kordyban, \& Kinash, 2013) teachers may have difficulty in understading whether the students do their responsibilities out of class or not. The biggest disadvantage for teachers is not preparing or broadcasting lecture videos but preparing in class activities and integrating them to flipped classroom approach (Ozdamli \& Asiksoy, 2016).

The flipped classroom model is developed pedagogically by using educational technologies to create the most efficient time for class activities. In this approach students can use technological equipments, develop their abilities, create interactive discussion conditions, discover dif- 
ferent learning methods with different learning acitivities. According to Millard (2012) flipped classroom approach increases students' active engagement in the class.

Learning models that have these characteristics can be found in the flipped classroom model . This is as stated by Arnold-Garza that active learning is not something foreign to the flipped classroom model. This is because the flipped classroom model provides more time for active learning activities in the classroom, and encourages educators to view that active learning is a core component, rather than increasing learning time (Arnold-Garza, 2014). The flipped classroom model is also a learning model that is in line with the dynamics of scientific and technological advances that appear to adopt, adapt and utilize technological advances, particularly information and communication technology.

Activists of the flipped classroom model view that advances in information and communication technology can be used positively to change the face of education for the better, especially in increasing the effectiveness and quality of learning. Bishop argues that there are two related movements that are combining to change the face of education. The first of these is a technological movement that enables amplification and duplication of information at an extremely lowcost (Wakabayashi, 2015). Bishop's statement provides an important message that one of the efforts to advance the world of education is to take advantage of technological advances. Technolo- gical tools are useful for delivering learning content effectively and massively, as well as being a solution to overcome difficulties when learning relies only on face-to-face in class.

The use of information and communication technology tools in learning the flipped classroom model enables students to channel their creativity. Creativity can only be born from the ability to think creatively. Therefore, unlike expository models, for example, which sometimes hinder students' creative thinking abilities, in the flipped classroom model, the creative thinking ability gets the right channel. It certainly supports the achievement of learning objectives related to improving mastery of scientific literacy abilities (Runco, et al., 2010).

Hypothesis testing is done through twolane Analysis of Variance (Anova), a parametric statistical calculation method used to examine the effect of two or more independent variables manipulated on the dependent variable (Rodriguez et al., 2018). The independent variable in this study is the learning model and creative thinking, while the dependent variable is scientific literacy.

\section{First Hypothesis Testing}

The first hypothesis is related to the difference in scientific literacy between the experimental class $\left(\mathrm{A}_{1}\right)$ and the control class $\left(\mathrm{A}_{2}\right)$. The first hypothesis is complete as follows:

Based on the Anava two path calculation results obtained $\mathrm{F}$-count $=10.7735$ and $\mathrm{F}$-table $=4.02$ at the significance level $\alpha=0.05$. This

Table 2. Calculation Results Summary Anova

\begin{tabular}{|c|c|c|c|c|c|c|}
\hline \multirow{2}{*}{ Source Variance } & \multirow{2}{*}{ Df } & \multirow{2}{*}{ SS } & \multirow{2}{*}{ MSS } & \multirow{2}{*}{$F_{\text {Calculation }}$} & \multicolumn{2}{|c|}{$\mathrm{F}$ table $\left(\mathrm{F}_{\mathrm{t}}\right)$} \\
\hline & & & & & $\alpha=0.05$ & $\alpha=0.01$ \\
\hline Flipped Classroom Inter-line (b) & 1 & 55.9545 & 55.9545 & 10.7736 & 4.02 & 7.08 \\
\hline Expository Intercolumn (k) & 1 & 55.9545 & 55.9545 & 8.8192 & 4.02 & 7.08 \\
\hline Interaction (I) & 1 & 55.9596 & 55.9596 & 32.2503 & 4.02 & 7.08 \\
\hline In Group & 40 & 334.9091 & 17.8832 & - & - & - \\
\hline Total & 43 & 768.9773 & - & - & - & - \\
\hline
\end{tabular}

Table 3. Summary of Tuckey Test Calculation Results

\begin{tabular}{lcccccccc}
\hline Value Data & \multicolumn{2}{c}{$\begin{array}{c}\text { Rata-rata } \\
\text { Kelompok }\end{array}$} & $\begin{array}{c}\text { RJK } \\
\text { Dalam }\end{array}$ & $\mathrm{n}$ & $\mathrm{Q}_{\mathrm{h}}$ & $\mathrm{Q}_{\mathrm{t}}$ & $\alpha$ & Kategori \\
\hline $\mathrm{A}_{1} \mathrm{~B}_{1}-\mathrm{A}_{2} \mathrm{~B}_{1}$ & 33.1818 & 25.3636 & 17.8832 & 11 & 8.6490 & 0.536 & 0.05 & Significant \\
$\mathrm{A}_{1} \mathrm{~B}_{2}-\mathrm{A}_{2} \mathrm{~B}_{2}$ & 25.6363 & 24.9090 & 17.8832 & 11 & 2.3967 & 0.536 & 0.05 & Significant \\
$\mathrm{A}_{1} \mathrm{~B}_{1}-\mathrm{A}_{1} \mathrm{~B}_{2}$ & 33.1818 & 25.6363 & 17.8832 & 11 & 8.9617 & 0.536 & 0.05 & Significant \\
$\mathrm{A}_{2} \mathrm{~B}_{1}-\mathrm{A}_{2} \mathrm{~B}_{2}$ & 25.3636 & 24.9090 & 17.8832 & 11 & 2.3967 & 0.536 & 0.05 & Significant \\
$\mathrm{A}_{1} \mathrm{~B}_{2}-\mathrm{A}_{2} \mathrm{~B}_{1}$ & 25.6363 & 25.3636 & 17.8832 & 11 & 8.3030 & 0.536 & 0.05 & Significant \\
$\mathrm{A}_{1} \mathrm{~B}_{1}-\mathrm{A}_{2} \mathrm{~B}_{2}$ & 33.1818 & 24.9090 & 17.8832 & 11 & 8.9464 & 0.536 & 0.05 & Significant \\
\hline
\end{tabular}


shows that the $\mathrm{F}$-count is greater than the $\mathrm{F}$ table $\left(F_{h}>F_{t}\right.$, ie $10.7735>4.02$ at $\left.\alpha=0.05\right)$ so that $\mathrm{H}_{0 \text { is }}$ rejected and $\mathrm{H}_{1 \text { is }}$ accepted. Meanwhile, the research data also showed that the average value in the experimental class $=29.2727$ and the average value in the control class $=26.6818$.

The results of these calculations mean that there are differences in scientific literacy between students who carry out learning using the flipped classroom model and students who carry out learning using expository models.

The size of the F-count which reached 10.7735 means that the difference in scientific literacy is included in the very significant category (Martinez-Hernandez et al., 2015). While the average value of the experimental class that is higher than the control class means that the scientific literacy of the experimental class is better than the control class.

The test results prove the truth of the first hypothesis which states there are differences in scientific literacy of students who carry out learning the flipped classroom model and students who carry out expository model learning. This means that the flipped classroom model is more effective than the expository model in developing scientific literacy.

The first hypothesis testing succeeded in proving the difference in scientific literacy between the experimental class and the control class. The difference in scientific literacy is evidenced through the F-count that is greater than the F-table and the difference in the average value of each class of research. The average value of the experimental class that is higher than the average value of the control class means that the flipped classroom model is more effective at developing scientific literacy than the expository model. The main cause of the difference in scientific literacy is the learning model. The experimental class uses the flipped classroom model, while the control class applies an expository model.

The success of the flipped classroom model in developing scientific literacy in this study can be explored and examined from the paradigm and learning process. The flipped classroom model is designed by utilizing technological advancements, especially information and communication technology, namely digital technology devices in the learning process. Therefore, this model includes active learning model (active learning) is based on the paradigm of a student-centered learning (McCarthy, 2016).

\section{Second Hypothesis Testing}

The second hypothesis relates to differ- ences in scientific literacy of groups of students with high levels of creative thinking in the experimental class $\left(\mathrm{A}_{1} \mathrm{~B}_{1}\right)$ and groups of students with high creative thinking levels in the control class $\left(\mathrm{A}_{2} \mathrm{~B}_{1}\right)$. The second hypothesis is complete as follows:

Based on the results of the calculation of the Tuckey Test results obtained F-count = 8.6490 and F-table $=0.536$ at the significance level $\alpha=0.05$. This means that the F-count is higher than the $\mathrm{F}$ table $\left(\mathrm{F}_{\mathrm{h}}>\mathrm{F}_{\mathrm{t}}\right.$, ie 8.6490> 0.536 at $\alpha=0.05$ ) so that $\mathrm{H}_{0}$ is rejected and $\mathrm{H}_{1}$ is accepted. Meanwhile, the data also showed the average value of a group of students with a high level of creative thinking in the experimental class $=33.1818$, while the average value of a group of students with a high level of creative thinking on grade control $=25.3636$.

The results of these calculations mean that there are differences in the scientific literacy of groups of students with high levels of creative thinking in the experimental class who carry out learning using the flipped classroom model and groups of students with high levels of creative thinking in the control class who carry out learning using expository models.

The magnitude of F-count which reached 8.6490 means that the difference in scientific literacy is included in the very significant category (Sales, 2014). While the average value of the group in the experimental class higher than the control class means that the flipped classroom model is more effective than the expository model in developing scientific literacy when applied to students with high levels of creative thinking.

The results of the test prove the truth of the second hypothesis which states that there are differences in scientific literacy between groups of students with high levels of creative thinking who carry out flipped classroom learning models and groups of students with high creative thinking levels who carry out expository learning models.

The second hypothesis testing succeeded in proving the differences in scientific literacy between groups of students with high levels of creative thinking in the experimental class and the control class. The difference in scientific literacy is evidenced through the F-count that is greater than the F-table and the difference in the average value in each group. The average value of a group of students with a level of creative thinking in the experimental class is higher than the control class. This means that the flipped classroom model is more effective than the expository model in developing scientific literacy when applied to stu- 
dents with high levels of creative thinking.

The success of the flipped classroom model develops scientific literacy in groups of students with high levels of creative thinking that cannot be separated from the characteristics of the flipped classroom model itself. As an active learning model (active learning) with the paradigm of student-centered learning ( student centered instruction ), the model flipped classroom is developed based on the principle that learning is actually an activity undertaken by a for-studentsand not made (Rusdi, 2017).

The learning model is an important factor that determines student learning patterns and activities. But each student is unique and has its own different characteristics between a student and other students. Similarly, in terms of the ability to think creatively. In the context of this study, to facilitate analysis, the characteristics of creative thinking are distinguished in two poles diametrically: high levels of creative thinking and low levels of creative thinking.

\section{Third Hypothesis Testing}

The third hypothesis is related to differences in scientific literacy groups of students with low levels of creative thinking in the experimental class $\left(\mathrm{A}_{1} \mathrm{~B}_{2}\right)$ and a group of students with low levels of creative thinking in the control class $\left(\mathrm{A}_{2} \mathrm{~B}_{2}\right)$. The third hypothesis is as follows:

Based on the Tuckey test results obtained F-count $=2.3967$ and F-table $=0.536$ at a significance level $\alpha=0.05$. This means that the F-count is higher than the $\mathrm{F}$ table $\left(\mathrm{F}_{\mathrm{h}}>\mathrm{F}_{\mathrm{t}}\right.$, ie 2.3967> 0.536 at $\alpha=0.05$ ) so that $\mathrm{H}_{0 \text { is }}$ rejected and $\mathrm{H}_{1}$ is accepted. Meanwhile, research data also shows that the average value of groups of students with low creative thinking levels in the experimental class $=25.6363$, and the average value of groups of students with low creative thinking levels in the control class $=24.9090$.

The results of these calculations indicate there are differences in the scientific literacy of groups of students with high levels of creative thinking who carry out learning using the flipped classroom model and groups of students with high levels of creative thinking who carry out learning using expository models.

The F-count value which reached 2.3967 means that the difference in scientific literacy is included in the significant category (Holcomb et al., 2018). While the average value of this group in the experimental class is indeed higher than the average value in the control class, but the difference is very small ( 25.6363 versus 25.3636 ). This can be interpreted that the effectiveness of the two learning models (the flipped classroom model and the expository model) is not much different in developing scientific literacy when applied to students with low levels of creative thinking. In other words, the factor of creative thinking has an effect on student learning success (student learning outcome), especially in learning that aims to develop scientific literacy.

The results of the test prove the truth of the third hypothesis which states that there are differences in scientific literacy between groups of students with low creative thinking levels who carry out learning flipped classroom models and expository models. Nevertheless, it should be underlined that the differences in scientific literacy in the two groups are not too significant. This can be seen in the difference in the average value that is not too large. Thus, although this third hypothesis can be accepted, the effectiveness of the two learning models (the flipped classroom model and the expository model) does not differ significantly in developing scientific literacy when applied to students with low levels of creative thinking.

The results of hypothesis testing indicate that there are differences in the scientific literacy of groups of students with low levels of creative thinking in the experimental class and the control class, but the difference is not much different. This can be seen from the average value of this group in the experimental class $=25.6363$, while in the control class $=24.9090$.

For students with low levels of creative thinking, the use of any learning model does not seem to have a significantly different effect on learning success. This is because in learning science, especially learning that aims to develop scientific literacy requires the ability to abstract to understand its concepts and principles, and it requires the ability to think critically and creatively.

In this regard, several arguments can be put forward. First, students with low levels of creative thinking find it difficult to take their own initiative and need more guidance or explanation to understand something (Suryanti, 2018). The difficulty of taking the initiative certainly affects the success of learning. Therefore, any learning model that is used by groups of students with a relatively high level of creative thinking will not significantly influence the understanding and mastery of the material.

Second, students with a low level of creative thinking tend to carry out learning as it is, so that it needs well-organized and systematic material as well as more detailed teacher explanations (Suryanti, 2018). The serial learning process is preferred by students with low creative thinking 
levels.

Third, students with low levels of creative thinking tend to carry out learning using deduction reasoning (Sommer, \& Ritzhaupt, 2018). The subject matter is presented in the form of general premises, then the various aspects are explained in detail. Learning patterns like this have an impact on the lack of ability to analyze or think analytically.

\section{Fourth Hypothesis Testing}

The fourth hypothesis is related to the effect of interaction between learning models with creative thinking on scientific literacy $(\mathrm{AxB})$. Based on the Anava two path calculation results obtained F-count $=32.25$ and $\mathrm{F}$-table $=4.02$ at the significance level $\alpha=0.05$. This means that the $\mathrm{F}$-count is higher than the $\mathrm{F}$ table $\left(\mathrm{F}_{\mathrm{h}}>\mathrm{F}_{\mathrm{t}}\right.$, i.e. $32.25>4.02$ at $\alpha=0.05$ ) so that $\mathrm{H}_{0 \text { is }}$ rejected and $\mathrm{H}_{1 \text { is }}$ accepted. Thus, there is the effect of interaction between learning models and creative thinking on scientific literacy. That is, the interaction between learning models with creative thinking affects the level of scientific literacy.

The F-count of 32.25 indicates that the interaction effect can be categorized as very significant (Gonzalez Rodriguez et al., 2018)potentially leading to traumatic endotheliopathy (EoT. Other evidence of the presence of interactions between the model of learning and creative thinking toward scientific literacy is an average value that is much different between groups $A_{1} B$ with group $\mathrm{A}_{2} \mathrm{~B}_{2}$ (the average value of the group $\mathrm{A}_{1} \mathrm{~B}_{1}=$ 33.1818 and average value average group $\mathrm{A}_{2} \mathrm{~B}_{2}=$ 25.3636).

Furthermore, because there is an interaction between learning models and creative thinking, it is necessary to further analyze all data groups (samples). This is intended to map the pattern or significance of interactions between the learning model and creative thinking. Further analysis is presented by the following data groups.

First , the analysis in group $\mathrm{A}_{1} \mathrm{~B}_{1}$, namely groups of students with high levels of creative

Table 4. Summary of Hypothesis Testing Results

\begin{tabular}{|c|c|c|c|c|}
\hline Hypothesis statistics & F-count & F-table $\alpha=0.05$ & Group Average Value & Conclusion \\
\hline $\begin{array}{l}\mathrm{H}_{0}: \mu \mathrm{A}_{1}=\mu \mathrm{A}_{2} \\
\mathrm{H}_{1}: \mu \mathrm{A}_{1}>\mu \mathrm{A}_{2}\end{array}$ & 10.7736 & 4.02 & $\begin{array}{l}\mathrm{A}_{1}=29.2727 \\
\mathrm{~A}_{2}=26.6818\end{array}$ & $\mathrm{H}_{0}$ rejected; $\mathrm{H}_{1}$ accepted \\
\hline $\begin{array}{l}\mathrm{H}_{0}: \mu \mathrm{A}_{1} \mathrm{~B}_{1}=\mu \mathrm{A}_{2} \mathrm{~B}_{1} \\
\mathrm{H}_{1}: \mu \mathrm{A}_{1} \mathrm{~B}_{1}>\mu \mathrm{A}_{2} \mathrm{~B}_{1}\end{array}$ & 8.6490 & 0.536 & $\begin{array}{l}\mathrm{A}_{1} \mathrm{~B}_{1}=33.1818 \quad \mathrm{~A}_{2} \mathrm{~B}_{1} \\
=25.3636\end{array}$ & $\mathrm{H}_{0}$ rejected; $\mathrm{H}_{1}$ accepted \\
\hline $\begin{array}{l}\mathrm{H}_{0}: \mu \mathrm{A}_{1} \mathrm{~B}_{2}=\mu \mathrm{A}_{2} \mathrm{~B}_{2} \\
\mathrm{H}_{1}: \mu \mathrm{A}_{1} \mathrm{~B}_{2}>\mu \mathrm{A}_{2} \mathrm{~B}_{2}\end{array}$ & 2.3967 & 0.536 & $\begin{array}{l}\mathrm{A}_{1} \mathrm{~B}_{1}=25.6363 \quad \mathrm{~A}_{2} \mathrm{~B}_{2} \\
=24.9090\end{array}$ & $\mathrm{H}_{0}$ rejected; $\mathrm{H}_{1}$ diterima \\
\hline $\begin{array}{l}\mathrm{H}_{0} \text { : Int. } \mathrm{A} \times \mathrm{B}=0 \\
\mathrm{H}_{1} \text { : Int. } \mathrm{A} \times \mathrm{B} \neq 0\end{array}$ & 32.2503 & 4.02 & - & $\mathrm{H}_{0}$ rejected; $\mathrm{H}_{1}$ accepted \\
\hline
\end{tabular}

thinking in the experimental class. In this group the achievement of student literacy is the highest seen from the average value of 33.1818. The majority of students in this group get high scores (on average and above average) so that scientific literacy is categorized as high. The achievement of high scientific literacy is due to the interaction between the flipped classroom model and the high level of creative thinking.

Second, the analysis in group $\mathrm{A}_{1} \mathrm{~B}_{2}$, namely groups of students with low creative thinking levels in the experimental class. In this group the achievement of scientific literacy is not too high seen from the average value which reached 25,6363. The number of students who score high (on average and above average) and students who score low (below average) is relatively balanced. This proves the interaction between the flipped classroom model and the low level of creative thinking, even though the interaction is not significant.

Third, the analysis in group $\mathrm{A}_{2} \mathrm{~B}_{1}$, namely groups of students with high levels of creative thinking in the control class. In this group the achievement of scientific literacy is categorized as low. This is because the majority of students in this group score below the average value. The average value of this group is 25.3636 . This also proves the interaction between expository models and high levels of creative thinking, even though the interactions tend to be negative (inhibiting creative thinking).

Fourth, the analysis in group $\mathrm{A}_{2} \mathrm{~B}_{2}$, namely the group of students with low levels of creative thinking in the control group. In this group the achievement of scientific literacy is categorized as very low in terms of the average value of only 24.9090 . The majority of students in this group received low scores (below the mean). The achievement of low scientific literacy is an indication of the interaction between expository models and low levels of creative thinking.

Based on the entire description of the results of hypothesis testing, the following summary is displayed which can be seen in the Table 4 . 
The Table 4 shows that all hypotheses can be accepted and proven true. This can be seen from the F-count greater than the F-table and the average value in each group of data.

\section{CONCLUSION}

The scientific literacy of the experimental class implementing the flipped classroom learning model is higher than the control class implementing the expository model of learning. This is evident from the average value in each class, which is 29.2727 versus 26.6818 .

The scientific literacy of groups of students with high levels of creative thinking in the experimental class who carry out the learning of the flipped classroom model is higher than the group of students with high levels of creative thinking in the control class who carry out expository model learning. This is evident from the average value in each group, which is 29.2727 versus 26.6818 .

The scientific literacy of groups of students with low creative thinking levels in the experimental class who carry out the learning of the flipped classroom model is higher than the group of students with low creative thinking levels in the control class who carry out expository model learning. This is evident from the average value in each group, which is 29.2727 versus 26.6818 .

Interaction occurs between learning models and creative thinking that affects scientific literacy. Anava two-path test results show that the $\mathrm{F}$-count $=32.25$ is greater than the F-table $=4.11$ at the significance level $\alpha=0.05$. This means that there is an influence of interaction between learning models and creative thinking on scientific literacy.

\section{REFERENCES}

Aaron, S., Jon, B., Kristin, D., Brian, B., Helaine, W. M., \& Arfstrom, P. K. M. (2014). Definition of Flipped Learning. Retrieved March 12, 2019, from https://flippedlearning.org/definition-offlipped-learning/

Alzoubi, A. M., Al Qudah, M. F., Albursan, I. S., Bakhiet, S. F., \& Abduljabbar, A. S. (2016). The Effect of Creative Thinking Education in Enhancing Creative Self-Efficacy and Cognitive Motivation. Journal of Educational and Developmental Psychology, 6(1), 117-130. https://doi. org/10.5539/jedp.v6n1p117

Arnold-Garza, S. (2014). The Flipped Classroom Teaching Model and Its Use for Information Literacy Instruction. Communications in Information Literacy, 8(1), 7-22. https://doi. org/10.15760/comminfolit.2014.8.1.161

Baumtrog, M. D. (2017). Others and imagination in reasoning and argumentation: Improving our critical creative capacity. Informal Logic, 37(2), 129-151. https://doi.org/10.22329/il.v37i2.4 769

Bausell, R. B. (1994). Conducting Meaningful Experiments: 40 Steps to Becoming a Scientist. Los Angeles: SAGE Publications.

Bergmann, J., Sams, A., \& Bruss, K. (2015). Watch and Learn; Flipped Learning. Retrieved September 10, 2010, from http://webcasts.astd. org/uploads/assets/264/document/TDFlippedLearning.pdf

Berman, E. A., \& Kuden, J. L. (2017). Scientific literacy. In Agriculture to Zoology (pp. 17-26). UK: Chandos Publishing.

Bishop, J., \& Verleger, M. (2013). Testing the flipped classroom with model-eliciting activities and video lectures in a mid-level undergraduate engineering course. In Proceedings - Frontiers in Education Conference, FIE (pp. 161-163). Atlanta. https://doi.org/10.1109/FIE.2013.6684807

Bristol, T. (2014). Flipping the Classroom. Teaching and Learning in Nursing, 9(1), 43-46. https://doi.org/https://doi.org/10.1016/j. teln.2013.11.002

Cooper, H., \& Valentine, J. C. (2001). Using Research to Answer Practical Questions about Homework. Educational Psychologist, 36(3), 143-153.

Eddy, G. S., \& Suryono, Y. (2019). Implementation of Online Learning Lessons in the Package C Program. Journal of Nonformal Education, 5(2), 117-124.

Fauziah, P., \& Kusumawardani, E. (2019). The Concept of Innovation Classes Through The Parent Partnership Model at School. Journal of Nonformal Education, 5(2), 189-196.

Freddi, A. M. S. (2019). Design of experiment." Design Principles and Methodologies. UK: Springer

Fulton, K. (2012). Upside down and inside out: Flip your classroom to improve student learning. Learning \& Leading with Technology, 39(8), 1217.

Gonzalez Rodriguez, E., Cardenas, J. C., Cox, C. S., Kitagawa, R. S., Stensballe, J., Holcomb, J. B., ... Wade, C. E. (2018). Traumatic brain injury is associated with increased syndecan-1 shedding in severely injured patients. Scandinavian Journal of Trauma, Resuscitation and Emergency Medicine, 26(1), 1-10. https://doi. org/10.1186/s13049-018-0565-3

Herreid, C. F., \& Schiller, N. A. (2013). Case studies and the flipped classroom. Journal of College Science Teaching, 42(5), 62-66.

Kellinger, J. J. (2012). The flipside: Concerns about the "New literacies" paths educators might take. The Educational Forum, 76(4), 524-536.

Kordyban, R., \& Kinash, S. (2013). No more flying on auto pilot: The flipped classroom. Education Technology Solutions, 56(1), 54-56.

Maharani, H. R., Sukestiyarno, S., \& Waluya, B. 
Wiwi Susanti et al. / Journal of Nonformal Education 6 (1) (2020) 51-60

(2017). Creative thinking process based on wallas model in solving mathematics problem. International Journal on Emerging Mathematics Education, 1(2), 177-184.

Martinez-Hernandez, K., Ikpeze, C., \& Kimaru, I. (2015). Perspectives on Science Literacy: A comparative study of United States and Kenya. Educational Research International, 4(2), 25-30.

McCarthy, J. (2016). Reflections on a flipped classroom in first year higher education. Issues in Educational Research, 26(2), 332-350.

Millard, E. (2012). Reasons Flipped Classrooms Work: Turning lectures into homework to boost student engagement and increase technologyfueled creativity. UK: University Business.

Overmyer, G. R. (2014). The Flipped Classroom Model for College Algebra : Effects on Student Achievement. Colorado: Colorado State University Fort Collins.

Ozdamli, F., \& Asiksoy, G. (2016). Flipped Classroom Approach. World Journal on Educational Technology, 8(8), 98-105.

Runco, M. A., Millar, G., Acar, S., \& Cramond, B. (2010). Torrance tests of creative thinking as predictors of personal and public achievement: A fifty-year follow-up. Creativity Research Journal, 22(4), 361-368.
Rusdi, A. (2017). Hubungan Kemampuan Membaca, Berpikir Kreatif dan sikap terhadap sains dengan Literasi Sains Pencemaran Lingkungan Siswa MAN Medan. Jurnal Pendidikan Biologi, 7(1), 72-80.

Sales, N. (2014). Flipping the classroom: Revolutionising legal research training. Legal Information Management, 13(4), 231-235.

Sanjaya, W. (2016). Strategi Pembelajaran Berorientasi Standar Proses Pendidikan. Jakarta: Prenadamedia Group.

Sommer, M., \& Ritzhaupt, A. (2018). Impact of the flipped classroom on learner achievement and satisfaction in an undergraduate technology literacy course. Journal of Information Technology Education, 17(1), 159-182.

Suryanti, I. M. L. N. (2018). Process skills approach to develop primary students' scientific literacy: A case study with low achieving students on water cycle. In IOP Conference Series: Materials Science and Engineering (Vol. 296, No. 1, p. 012030). IOP Publishing.

Wakabayashi, N. (2015). Flipped classroom as a strategy to enhance active learning. Kokubyo Gakkai zasshi. The Journal of the Stomatological Society, 81(1), 1-7. 